\title{
ARHITEKTES DAINAS DANNEBERGAS DEVUMS ARHITEKTŪRĀ 20. GADSIMTA OTRAJĀ PUSĒ
}

\section{ILZE GUDRO*, JĀNIS KRASTIN̦Š}

Rīgas Tehniskā universitāte

\begin{abstract}
Kopsavilkums. Rakstā atspoguḷots ievērojamās latviešu arhitektes Dainas Dannebergas devums Latvijas arhitektūrā, kā arī dzīves nozīmīgie notikumi un izaugsme. Dzīvojot un strādājot padomju varas gados, arhitekte projektējusi gan dzīvojamās, gan sabiedriskās ēkas, kas joprojām tiek izmantotas un kuru kultūrvēsturiskās nozīmes līmenis laika gaitā ir noteikti audzis. Atpazīstamākais arhitektes projektētais objekts ir Rīgas Politehniskā institūta (RPI), tagad Rīgas Tehniskās universitātes (RTU), studentu pilsētinna Ķīpsalā. Pie tās projektēšanas D. Danneberga strādāja no 1969. līdz 1986. gadam. Arhitekte izstrādājusi arī vairāku citu mācību iestāžu, kā arī sabiedrisko un dzīvojamo ēku projektus, kas realizēti gan Latvijā, gan ārpus tās.
\end{abstract}

Atslēgas vārdi: Daina Danneberga, RPI / RTU studentu pilsētiṇa Ķīpsalā, 20. gadsimta otrās puses arhitektūra.

\section{Dainas Dannebergas ǵimene}

D. Danneberga dzimusi 1929. gada 25. martā Rīgā Leontīnes Kimeles (dzimusi Krom) un Konstantīna Kimela (arī Kimmels, Kimmelis, Kimmelis) ǵimenē.

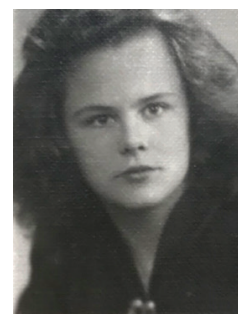

1. attēls. D. Danneberga (1952) [1].

\footnotetext{
* Korespondējošais autors.

E-pasts: ilze.gudro@rtu.lv
} 
Viṇas vecāki dzimuši Valkas apriṇķī: māte - Alsviķu pagastā, tēvs Annas pagastā. 1932. gadā Kimelu ǵimenē pasaulē nāca Dainas māsa Guna.

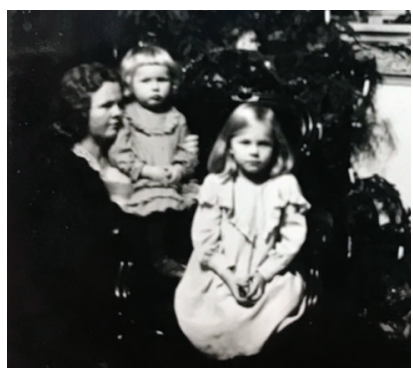

2. attēls. No kreisās - Dainas māte Leontīne, māsa Guna un Daina dzīvoklī Rīgā (ap 1934) [2].

D. Dannebergas māte un tēvs pēc profesijas bija drēbnieki. Otrā pasaules kara gados abi vecāki šo nodarbošanos turpināja ǵimenes šūšanas uzṇēmumā «K. Kimelis», ko bija dibinājis K. Kimela tēvs. Padomju laikos uzṇēmums tika likvidēts, un tēvs sāka strādāt par galveno piegriezēju šūšanas uzñēmumā «Sadarbība», bet māte kḷuva par mājsaimnieci. Veselības dēḷ viṇa vairs nevarēja darbu turpināt. Arī Daina vēlējās kḷūt par modisti, taču Padomju Savienībā šādu profesiju apgūt nebija iespējams.

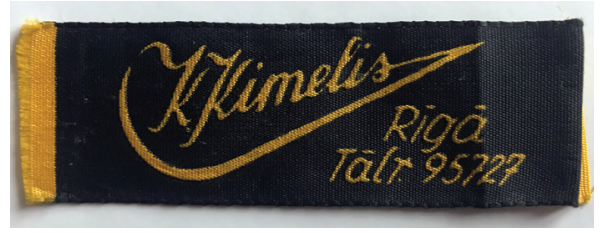

3. attēls. Šūšanas uzṇēmuma «K. Kimelis» logo (1940) [3].

Skolas gados kādā no skolēnu ballēm Daina iepazinās ar savu nākamo vīru Tālivaldi Dannebergu (1926-1958). Precības notika 1949. gadā šaurā ǵimenes lokā. Dainas vīrs bija Triju Zvaigžṇu ordeṇa kavaliera generāḷa Artūra Danneberga (1891-1941) dēls. Diemžēl Tālivaldis saslima ar tuberkulozi un 1958. gadā mira lıti jauns. Otro reizi D. Danneberga gredzenus mija 1960. gadā ar Ilgvaru Veigneru. Šajā laulībā dzimušas divas meitas.

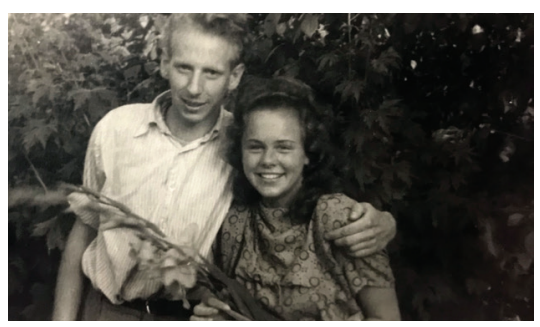

4. attēls. Dannebergi nedēḷu pēc kāzām Mellužos (1949) [4]. 


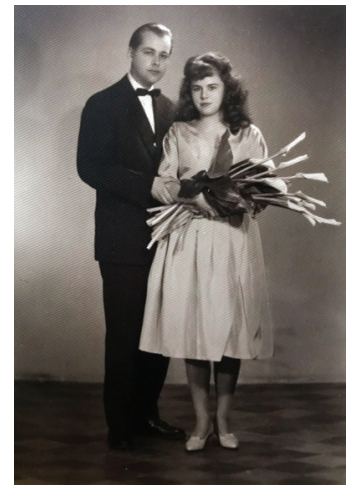

5. attēls. I. Veigners un D. Danneberga kāzu dienā (1960) [5].

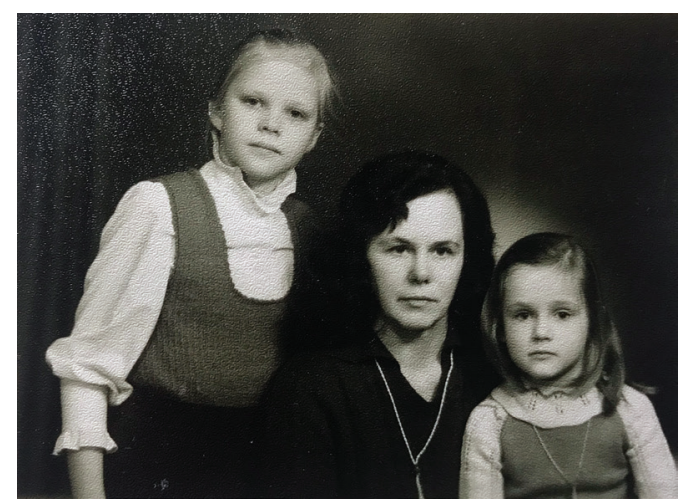

6. attēls. D. Danneberga ar meitām Helgu un Noru (ap 1980) [6].
Arhitektes

Dainas

Dannebergas

devums

arhitektūrā

20. gadsimta

otrajā pusē

\section{Dainas Dannebergas izglītība}

Skolas gaitas D. Danneberga sāka Rīgas 2. pamatskolā, ko pabeidza 1944. gadā. Pēc tam iestājās Rīgas 2. vidusskolā, ko pabeidza 1949. gadā [7].

Paralēli mācībām Daina dziedāja skolas korī un bija klases sienas avīzes redaktore. Vidusskolas direktore Dainu raksturoja kā apdāvinātu skolnieci ar asu un skaidru domāšanu, rosīgu sabiedriskajā darbā, kura daudz lasīja un sevišķi dzīvi piedalījās izlasītā debatēs, kā arī apmeklēja lekcijas Latvijas Padomju Sociālistiskās Republikas (LPSR) Pionieru pilī, teātrus, kino un operu [8].

Ar pirmo vīru Tālivaldi D. Dannebergai saistījās karjera, jo, tieši viṇa iedvesmota, Daina kluva par arhitekti. T. Danneberga mudināta, viṇa 1949. gadā iestājās Latvijas Valsts Universitātes (LVU) Arhitektūras fakultātē. Studiju laikā abi apprecējās. Par to liecina arī D. Dannebergas lūgums LVU Kadru daḷai mainīt uzvārdu viṇas personas lietā sakarā ar stāšanos laulībā.

7. attēls. LVU Kadru dalıai adresēta izziña par D. Dannebergas uzvārda mainu. 1949. gada 19. oktobris [9].

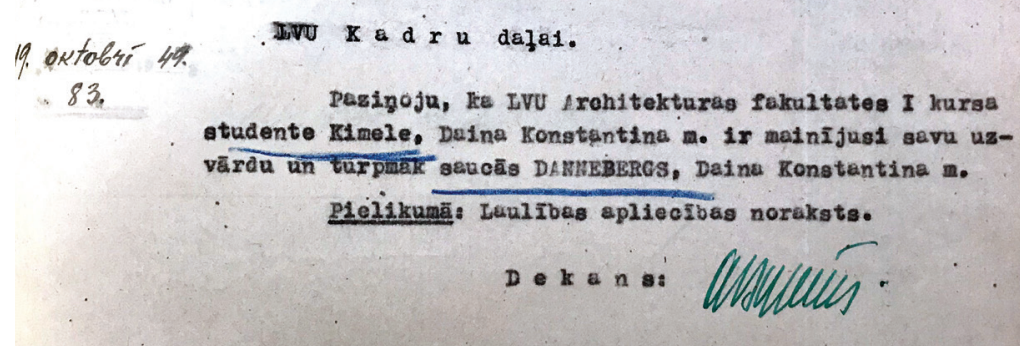


Studiju laiks universitātē saistījās ar izteiktām turbulencēm arhitektūras pamatnostādṇu definēšanā Padomju Sociālistisko Republiku Savienībā (PSRS) un daudzu profesionālu jautājumu politizēšanā. D. Danneberga ar pirmo vīru T. Dannebergu studēja vienā augstskolā, bet dažādos kursos. Sekmes abiem bija gana labas [10]. Vienā no augstskolas skates komisijas protokoliem laikā, kad notika diskusijas par Arhitektūras fakultātes slēgšanu, tika atzīmēts, ka daži no studentiem (arī D. Dannebergas vīrs Tālivaldis) slēpj savus darbus, lai veiktu labojumus, ka ir neuzticīgi iekārtai, jo ir buržuāziskie nacionālisti. Tālivaldis tika nepatiesi apvainots un sodīts - viņam lika izṇemt dokumentus no augstskolas. Solidarizējoties ar vīru, Daina 1952. gada 1. martā LVU vadībai iesniedza lūgumu atskaitīt vinuu no studējošo skaita gimenes apstākḷu dēḷ [11].

Kādu brīdi (20.03.1952-27.03.1952) Daina strādāja projektēšanas institūtā «Latgiprogorstroj» («Латгипрогорстрой») par kopētājuzīmētāju [12]. Nopelnītais tika izlietots zālēm vīra ārstēšanai. Tajā pašā 1952. gadā abi Dannebergi iestājās Lenningradas Inženierceltniecības institūta neklātienes nodaḷā Rīgā. 1954. gada vasarā abi pārgāja uz klātienes mācībām. Tālivaldis bija 4., bet Daina - 3. kursā. Abi vēlējās absolvēt institūtu reizē, tādēl Daina jau neklātienē bija nolikusi vairākus eksāmenus un turpināja paātrinātās studijas [13].

Daina mācījās pie arhitekta profesora Andreja Ọ̦a (Андрей Андреевич Оль; 1883-1958), kurš 20. gadsimta sākumā bija strādājis Somijā pie arhitektiem Armasa Eliela Lindgrēna (Armas Eliel Lindgren; 1874-1929) un Eliela Sārinena (Eliel Saarinen; 1873-1950), tur izkopdams labu gaumi un arhitektūras detal̦u kultūru. Profesors l̦oti ietekmēja Dainas turpmāko izpratni par moderno arhitektūru. D. Dannebergas diplomdarba tēma bija «Eksperimentālais dzīvojamais kvartāls L̦eñingradā» (1957).

Atgriežoties Rīgā, jaunā arhitekte strādāja kopā ar bijušajiem LVU kursabiedriem - Oḷgertu Kraukli, Modri G̦elzi, Viktoru Zilgalvi, Arvīdu Ceḷadomu, Irēnu Rubausku, Regīnu Jaunušāni, Albertu Kalmani, Vasīliju N̦ikiforovu u. c., kuri studijas bija beiguši 1955. gadā.

\section{Dainas Dannebergas darba gaitas}

Jau studiju laika prakses programmā Daina bija iesaistīta viesnīcas «Rīga» projektēšanā. Pēc atgriešanās no studijām L̦enningradā 20. gadsimta piecdesmito gadu beigās arhitekte kopā ar vīru Tālivaldi aktīvi piedalījās vairākos arhitektūras projektu konkursos.

Turpmākos piecus gadus viṇa strādāja dažādos amatos projektēšanas institūtā «Latgiprogorstroj» (tas vēlāk saucās «Pilsētprojekts») par tehniḳa vietas izpildītāju, tehniḳi, galveno tehniḳi, arhitekta vietas 
izpildītāju, arhitekti, bet kopš 1960. gada bija galvenās arhitektes amatā, ko pildīja līdz pat 1986. gadam.

1986. gada 1. novembrī arhitekti pieṇēma darbā RPI par mācību meistaru ar algu 120 rubḷu mēnesī. 1990. gada 16. janvārī D. Dannebergu pārcēla par mācību meistaru uz RPI Kapitālās celtniecības daḷu, kurā no 1991. gada 24. aprīḷa viṇa strādāja kā 1. kategorijas speciāliste. 1993. gada 1. septembrī pēc pašas lūguma viṇa darba attiecības ar RTU pārtrauca, taču līdz pat 1999. gada 3. decembrim - līdz aiziešanai pensijā - viṇa strādāja dažādus darbus RTU, galvenokārt saistībā ar RTU ipašumu sakārtošanu.

Īpašs uzplaukums arhitektes dail̦radē bija pagājušā gadsimta septindesmitajos un astondesmitajos gados, kad tapuši D. Dannebergas nozīmīgākie darbi. Kopš 1960. gada viṇa ir Latvijas Arhitektu savienības biedre.

\section{Dainas Dannebergas ievērojamākie projekti Latvijā un Kazahstānā}

20. gadsimta trīsdesmitajos gados visā pasaulē arhitektūrā uzplauka funkcionālisms jeb modernā kustība, kas palika kā dominējošais stils visu gadsimtu. Taču trīsdesmito gadu otrajā pusē attīstījās arī alternatīva, klasiskajā izteiksmes līdzekḷu arsenālā balstīta stilistika - neoeklektisms. Tas pēctecīgi turpinājās arī pēc Otrā pasaules kara, Padomju Savienībā iegūdams «sociālistiskā reālisma» nosaukumu. To mēdz dēvēt arī par «Stal̦ina ampīru» vai «Stal̦ina baroku». Šo retrospektīvo ievirzi direktīvā veidā pārtrauca Padomju Savienības Komunistiskās partijas Ministru Padomes 1955. gadā pieñemtie lēmumi «Par pārmērību novēršanu projektēšanā un celtniecībā» un «Par pasākumiem celtniecības tālākai industrializācijai, kvalitātes uzlabošanai un būvizmaksu samazināšanai». Tie arhitektūras attīstību ievirzīja laikmetīgākā gultnē, taču vispārējais celtniecības industrializācijas diktāts krasi ierobežoja arhitektūras radošo daudzveidību un individualitāti. Tomēr arī šādos apstākḷos D. Danneberga spēja radīt celtnes, kuras izcel̦as ar noteiktu arhitektoniski māksliniecisko kvalitāti.

Arhitektei izdevās piedalīties arī braucienos uz Polijas Tautas Republiku, Vācijas Demokrātisko Republiku (1968), Čehoslovākijas Sociālistisko Republiku, Ungārijas Tautas Republiku (1971), tādējādi paplašinot savu profesionālo zināšanu apvārsni. Viṇas darbu klāstā ir gan pilsētbūvnieciski risinājumi, gan dzīvojamās un publiskās ēkas.

Juglas dzìvojamo namu rajons «Jugla 3» Rīgā. 1958.-1963. Arhitekti D. Danneberga, O. Krauklis, A. Tītmane, S. Andersone, G. Melbergs, L. Nagliņš. Tas bija viens no pirmajiem lielajiem D. Dannebergas projektiem. Iepriekš šeit bija pilsētas nostūris ar nomalei 
toreizējais PSRS vadītājs N,ikita Hruščovs un deva norādījumu: «mums šādu celtni vajag Cel̦inogradā». Cel̦inograda bija no jauna izveidota galvenā pilsēta Hruščova izlolotajās neskartajās zemēs. Tagad tā ir Kazahstānas galvaspilsēta Nursultana.

Celtne Cel̦inogradā tika uzbūvēta latviešu arhitektu vadībā, kas divu gadu garumā tur veica operatīvos, kā arī ar tehniskās dokumentācijas sastādīšanu un autoruzraudzību saistītos darbus. Projekta izstrādāšanā līdz ar Latvijas Valsts pilsētu celtniecības projektēšanas institūtu piedalījās arī piecas Maskavas, L̦eningradas un Rīgas projektu organizācijas [20]. Zāles un foajē telpu mēbeles izgatavotas Rīgas I mēbel̦u kombinātā pēc Tautas Saimniecības Padomes Papīra un kokapstrādāšanas rūpniecības pārvaldes Centrālā konstruktoru biroja speciālistu zīmējumiem [21].

10. attēls. Cel̦inogradas neskarto zemju apguvēju pils plāns (1960).

Telpu apzīmējumi:

1 - galvenā ieeja;

2 - vestibils ar kasēm;

3 - vestibils;

4 - garderobe;

5 - foajē;

6 - kafejnīca;

7 - labierīcības;

8 - skatītāju zāle;

9 - estrāde;

10 - orkestris;

11 - aktieru telpas;

12 - tehniskās telpas;

13 - administrācija;

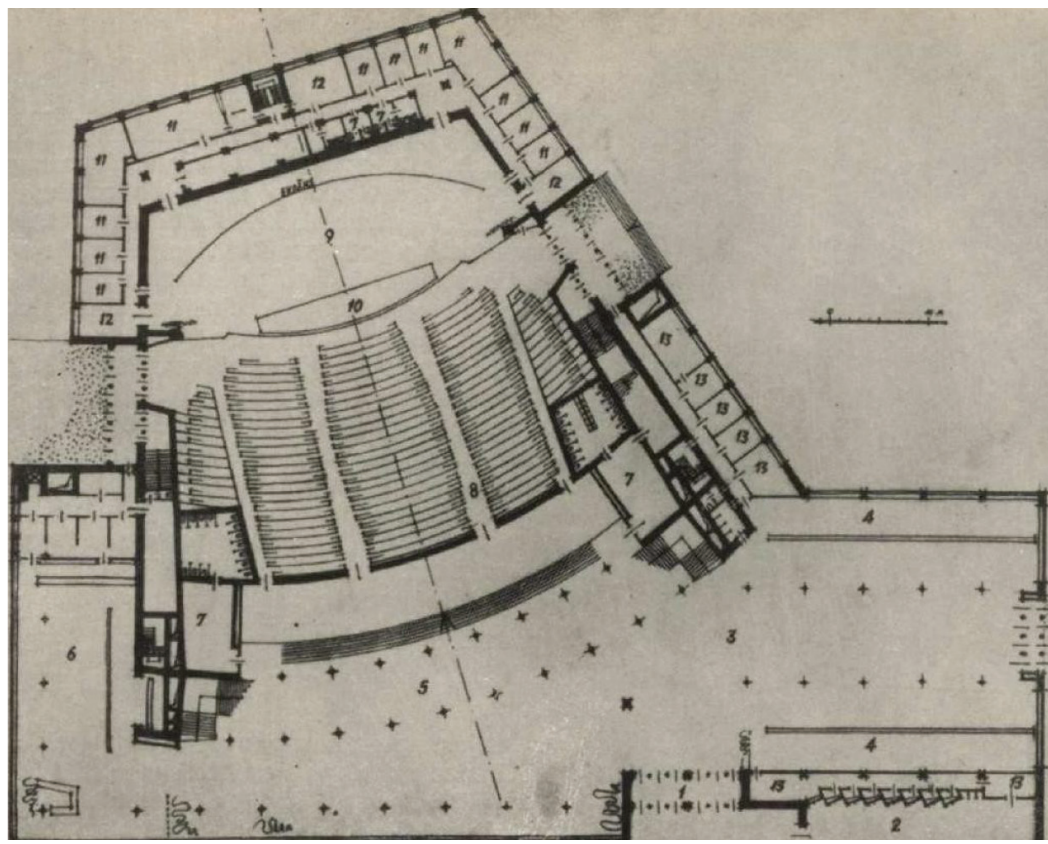

14 - terase [22].

Celtni parkā pilsētas galvenās ielas - Miera prospekta - galā tūlīt pēc nodošanas ekspluatācijā nosauca par «Jauno zemju apguvēju pili». Ēka bija redzama jau no vairāku kilometru attāluma. Apjomu kompozīcijas dominante - lielā zāle 2350 skatītājiem, kas paceḷas virs priekšpusē izvērstās, zemākās vestibila un foajē daḷas. Aizmugurē piekḷaujas divstāvu apjoms, kurā izvietotas palīgtelpas. Kopējā ēkas kubatūra $64000 \mathrm{~m}^{3}$, apbūves laukums - 0,54 hektāri, skatītāju zāle - 25 metru augsta. Kinoprojekciju telpā tika novietoti 10 kinoprojektori, 13 metrus augsts un 34 metrus plats kinoekrāns. Ārsienu stiklojumam izlietoja $962 \mathrm{~m}^{2}$ pulēta spoguḷstikla. 


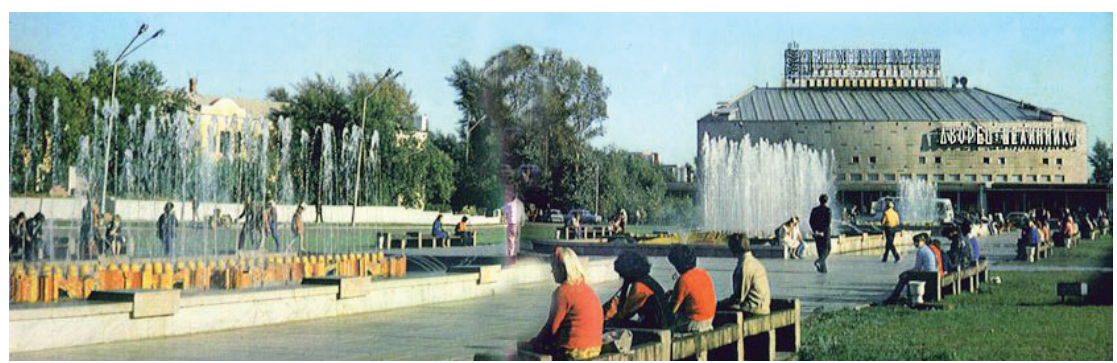

11. attēls. Skats uz Ceḷinogradas neskarto zemju apguvēju pils galveno fasādi (1963) [23].

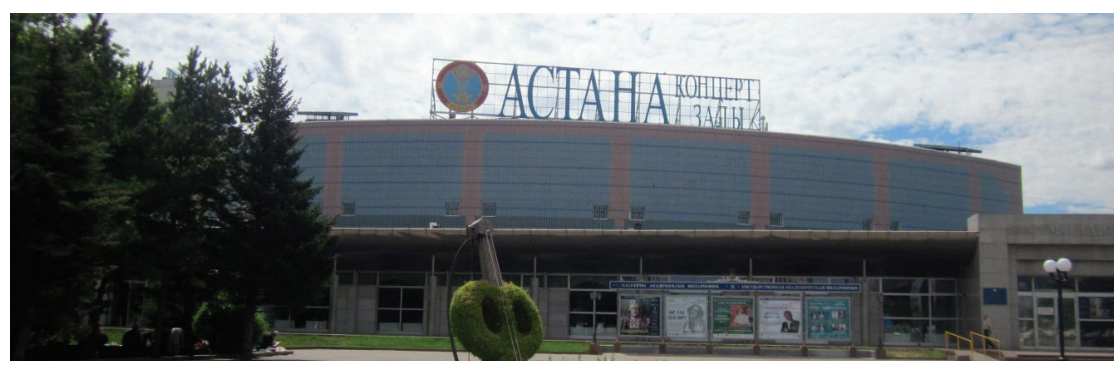

12. attēls. Skats uz Ceḷinogradas neskarto zemju apguvēju pils galveno fasādi (mūsdienās - Nurstultanas koncertzāle; līdz 2019. gada martam - Astanas) (2017) [24].

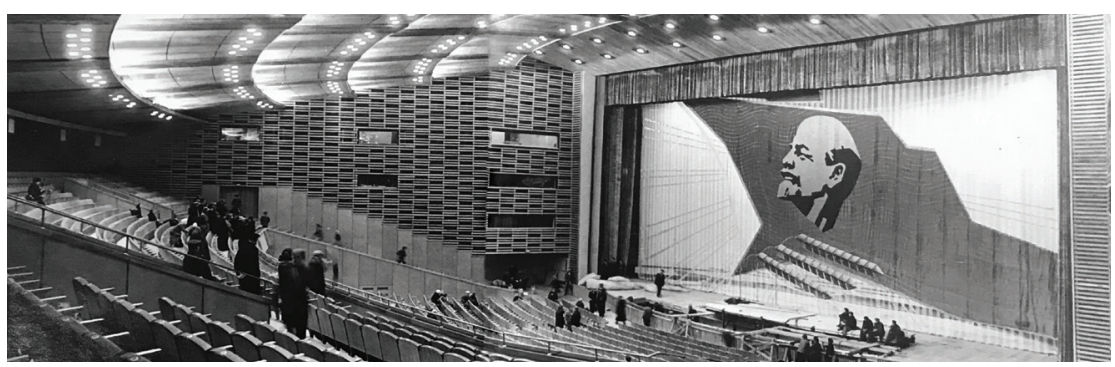

13. attēls. Ceḷinogradas neskarto zemju apguvēju pils skatītāju zāle (1963) [25].

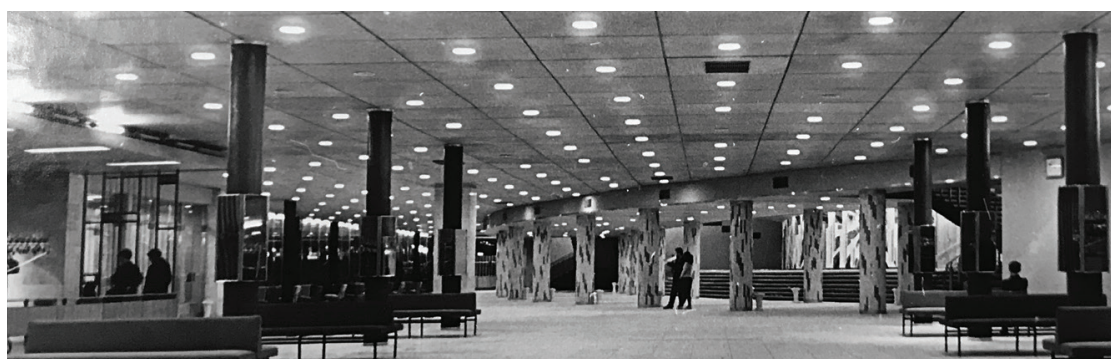

14. attēls. Cel̦inogradas neskarto zemju apguvēju pils foajē (1963) [26]. 
1963. gada sākumā D. Danneberga par dalību objekta īstenošanā saṇēma Vissavienības medal̦u «Par neskarto zemju apgūšanu».

Latvijas Zvejnieku kolhozu savienības nams Jaunielā 13, Rīgā. 1964.-1967. Arhitekte D. Danneberga. Rīgas Doma laukuma austrumu gals līdz Otrajam pasaules karam vēl bija blīvi apbūvēts. Karā tika iznīcināta apbūve gar Tirgoṇu ielu, bet kvartālā starp Rozena ielu un Jaunielu tika sagrauta èka Jaunielā 13. Saglabājusies eklektisma stilā celtā ēka Jaunielā 11 (1860; arhitekts Fridrihs Hess), kuras pirmajā stāvā 20. gadsimta septingdesmito gadu sākumā ierīkoja populāro kafejnīcu «13 krēsli», slējās kā vientul,š tornis klajā vietā. Tad tukšajā zemesgabalā Jaunielā 13 pēc arhitektes D. Dannebergas projekta tika uzcelts Latvijas Zvejnieku kolhozu savienības nams, aizpildot telpu starp ēku Jaunielā 11 un 18. gadsimtā celto dzīvojamo ēku Jaunielā 15. Šis nams organiski iekḷauts apkārtējā vidē un vienlaikus atspoguḷo ziemel̦niecisku pamatīgumu [27]. Nams tūlīt pēc tā uzcelšanas izpelnījās atzinību kā veiksmīgs kontekstuālas arhitektūras piemērs.

PSRS Arhitektu savienības rīkotajā radošajā skatē arhitekte par to tika apbalvota ar Goda diplomu [28].

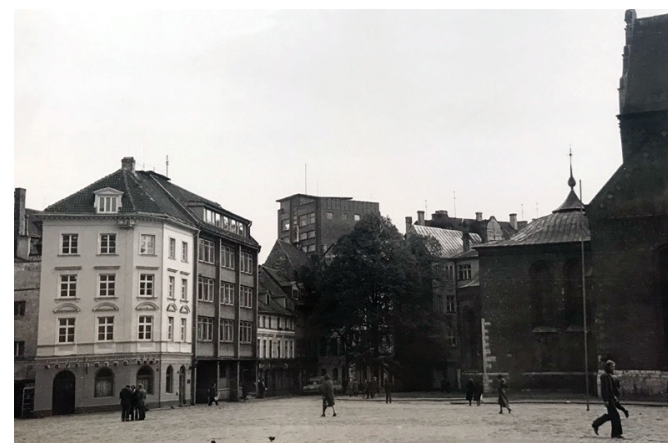

15. attēls. Latvijas Zvejnieku kolhozu savienības nams Jaunielā 13, Vecrīgā (ap 1970) [29].

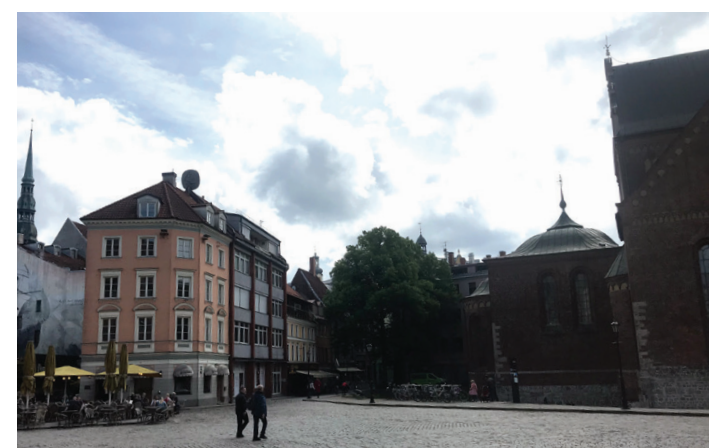

16. attēls. Latvijas Zvejnieku kolhozu savienības nams Jaunielā 13, Vecrīgā (2019) [30].

RPI studentu pilsētiṇa Rīgā, Ķīpsalā. 1969.-1986. Tas ir viens no pazīstamākajiem un apjomīgākajiem arhitektes D. Dannebergas būvobjektiem. To viṇa iesāka projektēt 1969. gadā, kad projektēšanas institūts «Pilsētprojekts» saṇēma RPI pasūtījumu izstrādāt tehniski ekonomisko pamatojumu visa RPI kompleksa izvietojumam Ķīpsalā. Pirmo Ķīpsalas studentu pilsētiṇas izbūves generālo plānu izstrādāja arhitekti Jānis Vilcinsš un Uldis Zaḳis. Pēc tam plānojumu turpināja Kārlis Alksnis un D. Danneberga.

Sākumā D. Danneberga strādāja pie programmas sastādīšanas RPI Ķīpsalas studentu pilsētiṇai, paredzot, ka RPI studēs vairāk nekā 10000 studentu. Tajā laikā jau bija uzcelta Radiotehnikas un sakaru 
fakultātes ēka (1968), kuru arhitekte papildināja ar trīs apjomīgu auditoriju bloku. Pilsētiṇa tika iecerēta pēc tā sauktā paklāja tipa apbūves principa, teritoriju vienmērīgi piepildot ar telpiski un funkcionāli saistītiem mācību korpusiem. Tika paredzētas arī studentu kopmītnes (dienesta viesnīcas), studentu ēdnīca 600 vietām, dzīvojamās ēkas mācībspēkiem un bērnudārzs. Bija plānotas divas studentu kopmītnes, bet uzcēla tikai vienu. Otras vietā vēlāk tika izveidota viesnīca «Islande». Pie kompleksa dạ̦ēji pieskaitāms arī peldbaseins, bet dzīvojamās ēkas mācībspēkiem un bērnudārzu nemaz nesāka celt.

Katra mācību korpusa būvniecībai tika piešķirti 2,5 miljoni rubḷu. Atsevišķas ēkas nācās izveidot, galvenokārt izmantojot tikai iepriekš izgatavotas dzelzsbetona konstrukcijas.

Mācību korpusiem atbilstoši padomju laika normatīviem bija jābūt ne vairāk kā četrus stāvus augstiem. Arhitektūras un celtniecības fakultātes augšējais, piektais stāvs - Arhitektūras katedras zīmētava - veidots individuālās konstrukcijās. Arī virsgaismas logus, kas lietoti šajā telpā, tajos laikos neražoja. Tika atrasts jumiķsis, kurš pēc individuāla pasūtījuma šādus logus izgatavoja - ar dubultstiklu un slīpumu uz vienu pusi ūdens notecei.

Individuāls arhitektoniskais veidols ir studentu kopmìtnēm. To projekts tika izstrādāts kopā ar arhitekti Baibu Maiki. Katram studentam noteiktos $6 \mathrm{~m}^{2}$ arhitektes paplašināja līdz $14 \mathrm{~m}^{2}$. Savdabīgi bija risināta kopmītñu fasāžu apdare. Tās tika apšūtas ar glazētām keramikas plāksnītēm, ko izgatavoja rūpnīcā «Lode» [31].

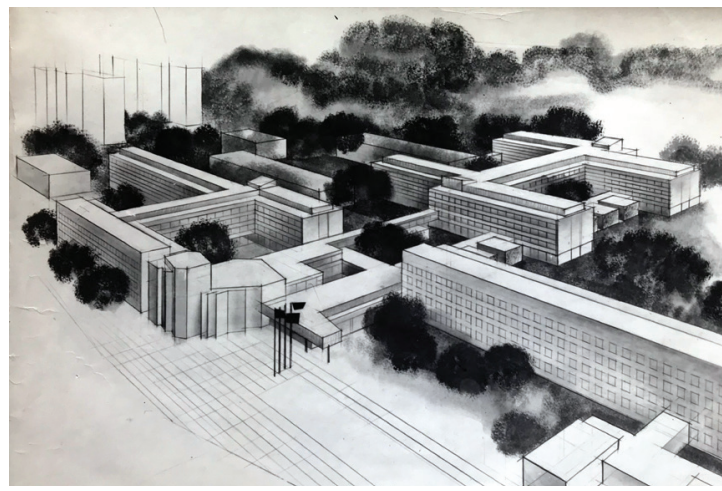

17. attēls. Projektēšanas institūtā «Pilsētprojekts» skice - RPI studentu pilsētiṇa Ķīpsalā, kopskats (1969) [32].

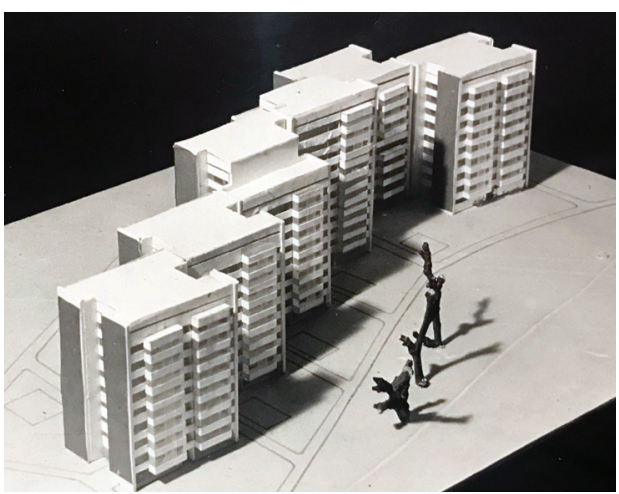

18. attēls. Arhitektes Dainas Dannebergas (kopā ar arhitekti Baibu Maiki) RPI Ķīpsalas studentu kopmītñu makets (20. gadsimta astondesmitie gadi) [33]. 
D. Dannebergas vadībā RPI Ķīpsalas studentu pilsētiṇā no 1970. līdz 1986. gadam tapa vesela virkne ēku (1. tabula).

D. Dannebergas vadībā projektētās ēkas RPI Ķ̄īpsalas studentu pilsētiṇā no 1970. līdz 1986. gadam

\begin{tabular}{|c|c|c|}
\hline $\begin{array}{c}\text { Gads, kurā } \\
\text { ēka nodota } \\
\text { ekspluatācijā }\end{array}$ & $\begin{array}{c}\text { Sākotnējā funkcija un } \\
\text { adrese }\end{array}$ & $\begin{array}{c}\text { Tagadējā funkcija un } \\
\text { adrese }\end{array}$ \\
\hline 1970 & $\begin{array}{l}\text { Ķīmijas fakultātes } \\
\text { laboratoriju korpuss gar } \\
\text { Zunda kanālu } \\
\text { (Āzenes iela 14) }\end{array}$ & $\begin{array}{l}\text { Materiālzinātnes un lietišķās } \\
\text { ķimijas fakultātes } \\
\text { (MLĶF) ēka } \\
\text { (Paula Valdena iela 7) }\end{array}$ \\
\hline 1975 & $\begin{array}{l}\text { Celtniecības fakultātes } \\
\text { mācību un laboratoriju ēka } \\
\text { (Āzenes iela 16) }\end{array}$ & $\begin{array}{l}\text { Mašinzinību, transporta un } \\
\text { aeronautikas fakultātes èka } \\
\text { (Ķīpsalas iela 6B) }\end{array}$ \\
\hline 1975 & $\begin{array}{l}\text { Studentu èdnīca ar } 600 \\
\text { vietām } \\
\text { (Āzenes iela 18) }\end{array}$ & $\begin{array}{l}\text { 2013. gadā pārbūvēta. } \\
\text { Tajā atrodas Arhitektūras } \\
\text { fakultāte un MLĶF Dizaina } \\
\text { tehnologiju institūts } \\
\text { (Ķ̄īpsalas iela 6) }\end{array}$ \\
\hline 1978 & $\begin{array}{l}\text { Celtniecības fakultātes otrais } \\
\text { korpuss } \\
(\bar{A} \text { zenes iela } 20)\end{array}$ & $\begin{array}{l}\text { Būvniecības inženierzinātṇu } \\
\text { fakultātes ēka } \\
\text { (Ķ̄īpsalas iela 6A) }\end{array}$ \\
\hline 1980 & $\begin{array}{l}\text { Studentu kopmītnes pirmais } \\
\text { korpuss } \\
\text { (Āzenes iela 22) }\end{array}$ & $\begin{array}{l}\text { Studentu } \\
\text { dienesta viesnīca } \\
(\bar{A} z e n e s \text { iela } 8)\end{array}$ \\
\hline 1983 & $\begin{array}{l}\text { Ķìmijas fakultātes otrais } \\
\text { korpuss } \\
(\bar{A} z e n e s \text { iela } 24)\end{array}$ & $\begin{array}{l}\text { MLĶF otra ēka } \\
\text { (Paula Valdena iela 3) }\end{array}$ \\
\hline 1985 & $\begin{array}{l}\text { Ķīmisko reaktīvu noliktavas } \\
\text { ēkas projekts, sāka celt } \\
\text { 1988. gadā (finansējuma } \\
\text { trūkuma dēl celtniecība } \\
\text { apstājās 1996. gadā) }\end{array}$ & $\begin{array}{l}\text { 1999. gadā ēku pārbūvēja par } \\
\text { RTU Zinātnisko bibliotēku, } \\
\text { (Paula Valdena iela 5) }\end{array}$ \\
\hline 1986 & $\begin{array}{l}\text { Otrs } 11 \text { stāvu studentu } \\
\text { kopmītnes korpuss } \\
\text { (Āzenes iela 22a) }\end{array}$ & $\begin{array}{l}\text { Studentu } \\
\text { dienesta viesnīca } \\
(\bar{A} z e n e s \text { iela } 6)\end{array}$ \\
\hline
\end{tabular}




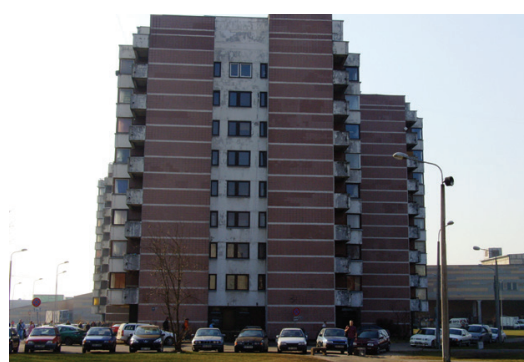

19. attēls. Skats uz RPI Kīipsalas studentu kopmītnēm (2008) [34].

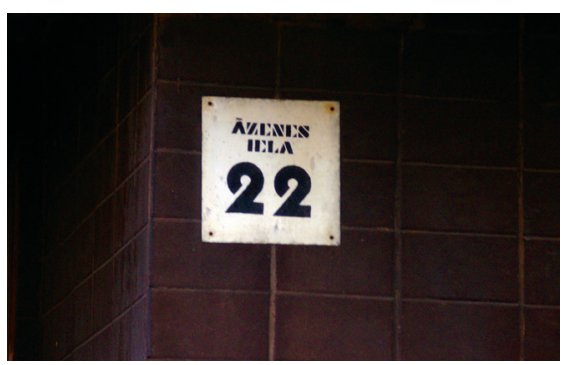

20. attēls. Glazētās keramikas plāksnītes uz RPI Ķīpsalas studentu kopmītṇu fasādēm (2008) [35].

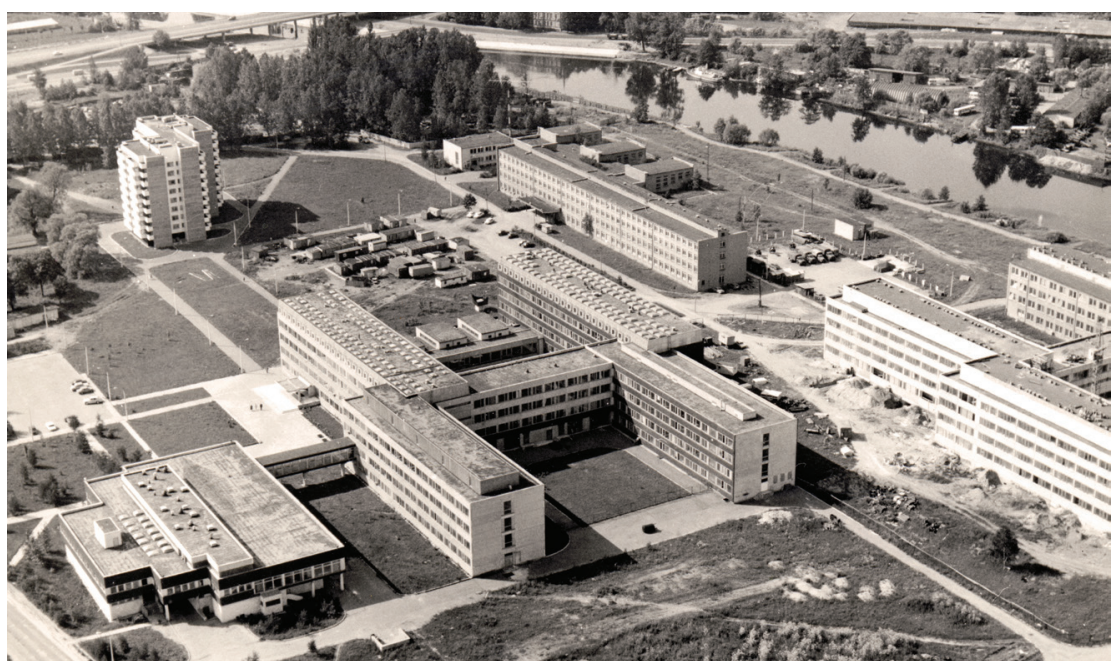

21. attēls. Skats uz RPI studentu pilsētiṇu Ķīpsalā

(20. gadsimta astondesmitie gadi) [36].

Juglas sanatorijas Meža skola Stopiṇu pagasta Upeslejās. 1971.1977. Līdztekus RPI projektēšanai arhitekte D. Danneberga radījusi arī citus sabiedriski nozīmīgus objektus. Viens no tiem ir Juglas Sanatorijas Meža skolas (tagad Rīgas Sanatorijas internātpamatskolas) komplekss.

Mazās Juglas un priežu sila ielokā, starp simtgadīgām liepām un ozoliem, kur pavasaros visātrāk uzplaukst ziedi, bet Jān,os viskošāk iedegas ugunskuri, 1974. gadā sāka celt jaunu «muižu», kas domāta bērniem [37]. Skola bija paredzēta 400 audzēkṇiem, kam nepieciešams uzlabot un nostiprināt veselību. Kompleksu veido 11 atsevišksi paviljoni, kas savienoti ar kopējo centrālo komunikāciju. Pirmajos stāvos ir klases dažāda vecuma bērniem, ēdnīca, aktu zāle, sporta zāle ar val̦ēju pagalmu, slimnīca, darbnīca, vel̦as mazgātava; bet otrajos un trešajos stāvos - internāts un atpūtas zona [38]. Katram korpusam sava ieeja un garderobe, 
kā arī iekšējais pagalms, kurā pavasarī un rudeṇos stundu starplaikos iespējams ieelpot svaigu gaisu un izskrieties.

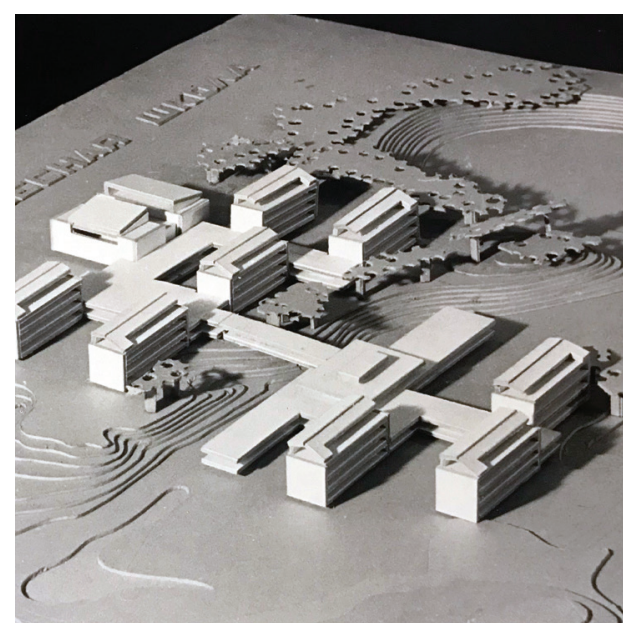

22. attēls. Juglas sanatorijas Meža skolas makets (1971) [39].

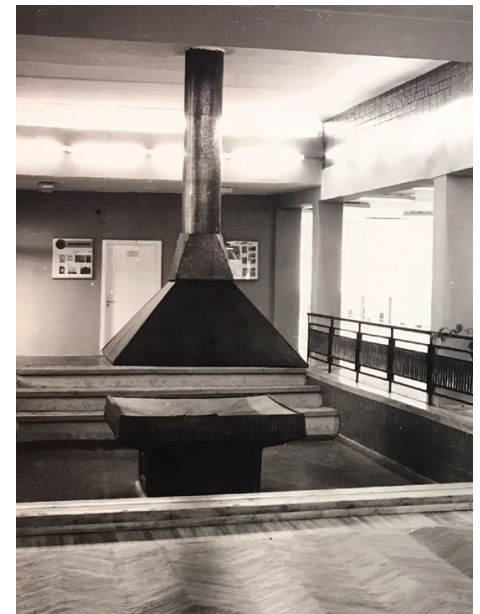

23. attēls. Juglas sanatorijas Meža skolas brīvstāvošais kamīns (1977) [40].

Paviljoni ir labi izsauḷoti un vēdināmi. Tie organiski iekḷaujas apkārtējā dabas vidē. Spēcīgs emocionālās izteiksmes kāpinājums panākts gaišā lieltelpā, kas atrodas pirmsskolas un vidusskolas klašu apjomu savienojuma vietā. Tur novietots brīvstāvošs kamīns - simbolisks ugunskurs [41].

Ar visas celtnes strukturāli pamatoto estētismu un logiski ritmizēto fasāžu izteiksmes valodu arhitekte pārliecinoši demonstrējusi savu profesionālo briedumu. Tā ir pamatīga, skaidra un pārdomāta arhitektūra [42].

Dzīvojamā ēka ar bērnudārzu Rīgā, Brīvības gatvē 362. 1980. Arhitekti D. Danneberga, A. Ārgale, A. Kokins. Laikā, kad daudzstāvu dz̄̄vojamo ēku būvniecība tika masveidīgi īstenota pēc tipveida projektiem, arhitektiem dažkārt izdevās arī tiem pieškkirt individuālus vaibstus [43] Viens no šādiem piemēriem ir 70 dzīvokḷu dzīvojamā ēka Brīvības ielā 362, Stāmerienas ielas stūrī Rīgā. Vairāksekciju ēkas apjoma stūrus bija paredzēts akcentēt ar Rīgas vēsturiskajai apbūvei raksturīgiem stūra torñiem, bet pirmajā stāvā izbūvēt bērnudārzu. Uzbūvētas tika tikai dažas sekcijas un viens tornis. Stāmerienas ielas stūrī vēlāk uzbūvēta pavisam cita celtne. D. Dannebergas kopā ar kolēǵiem radītā ēka joprojām saista uzmanību ar elegantajām fasādēm, kurās spēcīgi izvirzīti erkeri sablokẹēti ar noapalıotas konfigurācijas balkoniem. 


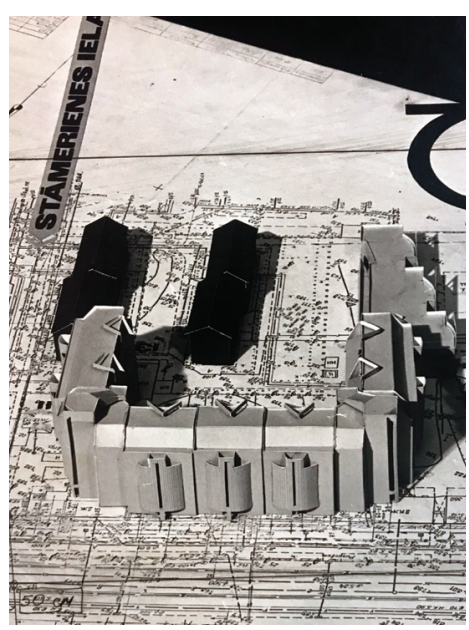

24. attēls. Dzīvojamās ēkas ar bērnudārzu makets Stāmerienas ielā (1980) [44].

Bulduru sovhoztehnikums Jūrmalā, Viestura ielā 6. 1973.-1990. Arhitekti D. Danneberga un A. Ārgale. Celtne ir diezgan apjomīgs dažāda rakstura funkcijām paredzētu telpu komplekss ar sarežgìitu, bet līdzsvarotu apjomu kompozīciju. Celtnes arhitektūrā veiksmīgi izspēlēts gan apdares materiālu tonalitātes, gan arhitektonisko formu rakstura kontrasta princips. Kompleksa centrālajā daḷā, kur atrodas mācību un administrācijas telpas, veidota kā kubisku apjomu salikums. Tajā uz dzelteno k̦ieǵeḷu plašu, neitrālu virsmu fona izcel̦as balti būvḳermeṇi ar asi iezīmētiem lentveida logiem. Ar šìm formām vienlaikus gan kontrastē, gan harmoniski saaug kompleksa spārni, kuros izvietotas mācību oranžērijas un palīgtelpas. Savdabīgi veidotā celtne veiksmīgi ierakstīta Jūrmalas smalkajā arhitektoniskajā ainavā un korekti sadzīvo ar 20. gadsimta sākumā celto Dimdoṇa dārzkopības tehnikuma ēku puduri kompleksa priekšplānā [45]. Tagad èkā atrodas Bulduru Dārzkopības vidusskola. Vienlaikus ar skolas kompleksa celtniecību tika domāts arī par skolotāju un skolēnu dzīves kvalitātes uzlabošanu. Tāpēc tika izprojektētas gan skolotāju dzīvojamās ēkas, gan skolēnu kopmītnes. Kopmītṇu projekts devin, desmito gadu politisko un ekonomisko apstākḷu izmaiṇu dēl palika neīstenots.

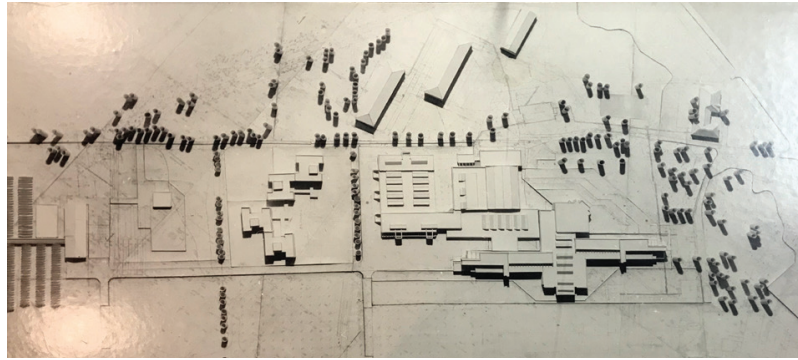

25. attēls. Bulduru sovhoztehnikuma makets Jūrmalā, Viestura ielā 6 (1973) [46]. 


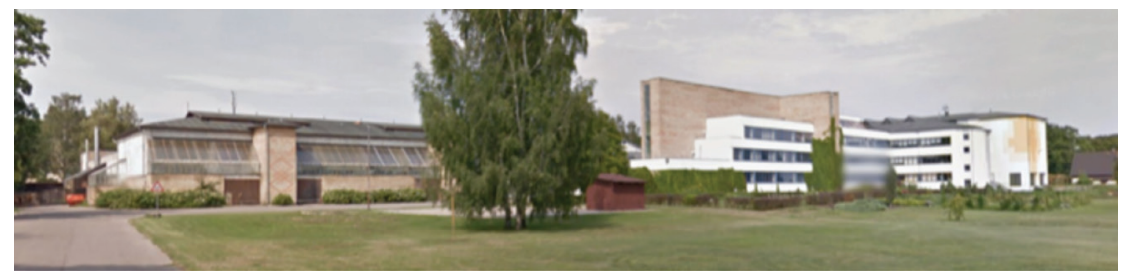

26. attēls. Bulduru sovhoztehnikums Jūrmalā, Viestura ielā 6 (2017) [47].

Viens no pēdējiem D. Dannebergas objektiem bija dzīvojamā ēka ar veikalu Brīvības gatvē 231/1 (1985). 1996. gadā D. Danneberga piedalījās RTU viesnīcas «Laine» pārbūvē, bet 1998. gadā izstrādāja projektu dzīvojamai ēkai ar garāžu Jūrmalā, Kanālu ielā 5.

27. attēls. Dzīvojamā ēka ar veikalu Brīvības gatvē 231/1 (1985) [48].

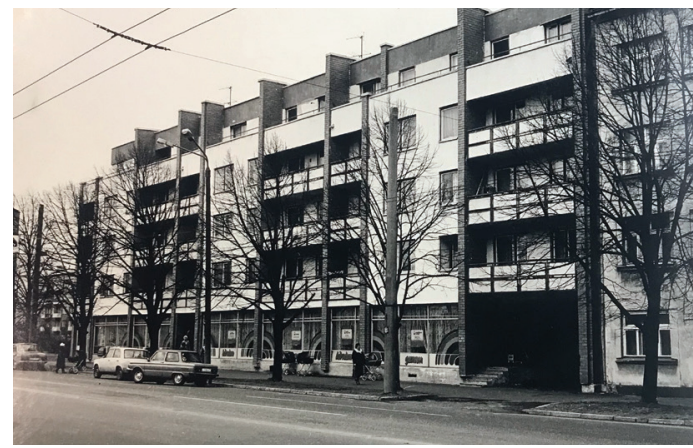

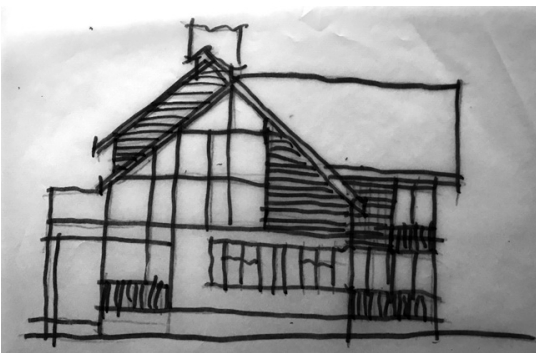

28. attēls. D. Dannebergas skice dzīvojamās ēka ar garāžu Jūrmalā Kanāla ielā 5 (2015) [49].

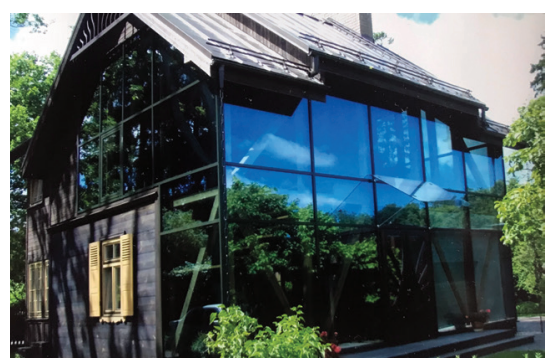

29. attēls. Dzīvojamā ēka ar garāžu Jūrmalā Kanāla ielā 5 (2015) [50].

Kā katra arhitekta praksē, vairāki projekti palikuši nerealizēti. 1958. gadā D. Danneberga un T. Dannebergs piedalījās konkursā par labāko tipveida projektu mazstāvu individuālo dzīvojamo ēku celtniecībai LPSR pilsētās un ciemos. Konkursu organizēja LPSR Ministru Padomes Valsts celtniecības un arhitektūras komiteja kopā ar LPSR Arhitektu savienību. Konkursa mērķis bija iegūt labus, ekonomiskus un LPSR klimatiskajiem un sadzīves apstākḷiem piemērotus divstāvu rindu 
ēku un trīs dzīvokḷu bloḳētu dzīvojamo ēku projektus, lai tos izmantotu jauna tipa projektu izstrādāšanai kooperatīvo un kolektīvo, kā arī individuālo dzīvojamo ēku celtniecībai. Saskaņā ar konkursa programmu pie katra dzīvokḷa bija jāparedz savs zemes gabals 400-600 m² platībā. Pavisam konkursam bija iesniegti 32 projekti. D. Danneberga un T. Dannebergs ieguva godpilno otro vietu un prēmiju - 5000 rubḷu. Viṇu projekta vērtējumā atzīmēts, kas tas izceḷas ar vienkāršu, vietējiem apstākḷiem piemērotu ēkas plānu un konstruktīvo risinājumu, bet ēkas arhitektūra un ārējā apdare ir gaumīga un atturīga [51].

1959. gadā D. Danneberga kopā ar arhitekti Elgu Krastinuu piedalījās LPSR kūrortu pilsētās un pilsētu zal̦ajās zonās paredzētu vasarnīcu un dārza mājiṇu projektu konkursā, kuru organizēja LPSR Ministru Padomes Celtniecības un arhitektūras komiteja kopā ar LPSR Arhitektu savienību un Rīgas pilsētas Darbaḷaužu deputātu padomes izpildkomiteju. Konkursā tika iesniegti 19 projekti. Abas arhitektes ieguva pirmo vietu un 4000 rubḷu lielu prēmiju [52].
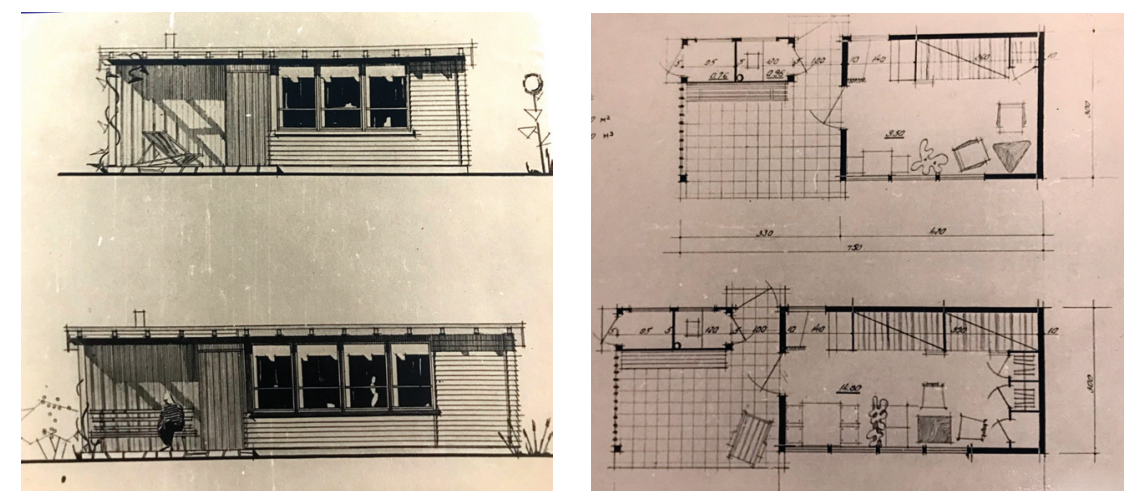

30. attēls. D. Dannebergas un E. Krastiṇas vasarnīcas un dārza mājiṇas projekts (1959) [53].

1959. gadā D. Danneberga kopā ar P. Fogeli, E. Krastinu un O. Kraukli piedalìjās jaunā Dailes teātra ēkas projekta izstrādāšanā kvartālā starp Sarkanarmijas (tagad Bruṇinieku), L,enina (tagad - Brīvības) un Šarlotes ielu. No iesniegtajiem 25 projektiem konkursa žūrija izraudzījās sešus projektus, no kuriem trīs prēmēja, bet trīs atpirka. Pēdējo vidū bija arī D. Dannebergas un viṇas kolēǵu projekts, par kuru piešķīira 4000 rubḷu prēmiju [54].

1960. gadā bija plānots Rīgā uzcelt panorāmas kinoteātri ar 2300 skatītāju vietām. Valsts projektu celtniecības institūta arhitekti 0. Fogels, O. Krauklis un D. Danneberga [55] - izstrādāja projektu jaunajam kinoteātrim. 


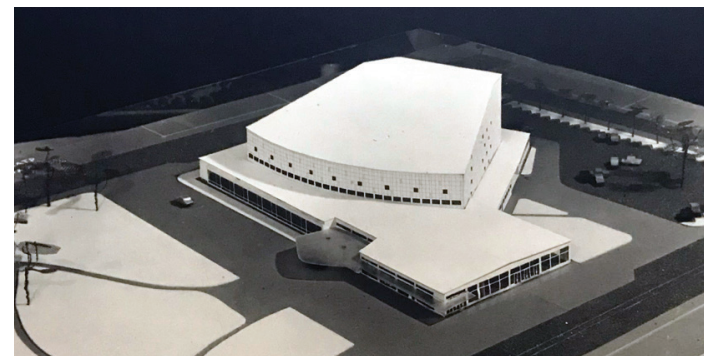

31. attēls. Rīgas panorāmas kinoteātra makets (1960) [56].

Projektēt šādu kinoteātri bija sarežǵīti, jo panorāmas kinoiekārta ir daudz komplicētāka nekā platekrāna. Panorāmas kino īpatnības radīja nepieciešamību radīt jauna veida celtni, kas radikāli atšķīās no agrāk pazīstamiem kinoteātriem. Celtniecībai tika izvēlēts apbūves gabals, ko norobežoja K. Barona, Artilērijas, P. Stučkas (tagad - Tērbatas) un Lielgabalu ielas. Kinoteātria novietotne - kvartāla ziemel̦u pusē, atstājot dienvidu dalı skvēra iekārtošanai. Kvartālā bija paredzētas stāvvietas 80 automašīnām. Kinoteātra celtnes projektā bija divi būvḳermeṇi. Dominējošais elements bija augstais zāles korpuss, kas izaug no vienstāva apkalpojošo telpu grupas. Vestibilā bija paredzēts foajē un bufetes telpas. No foajē plašas kāpnes veda skatītājus zālē ar 2300 vietām [57]. Kā jau iepriekš minēts, Rīgas pilsētas panorāmas kinoteātra projekts tika realizēts Ceḷinogradā.

32. attēls. Rīgas panorāmas kinoteātra projekts (1960) [58].

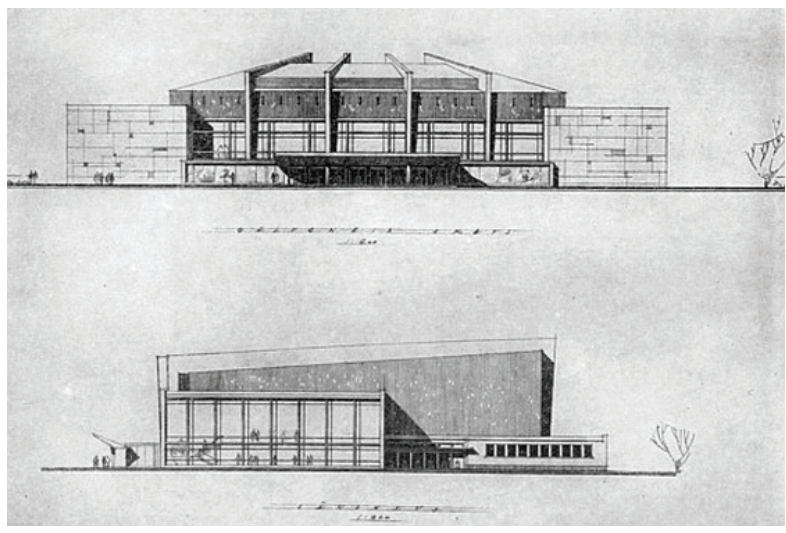

1967. gadā D. Danneberga kopā ar arhitektu Andri Purviṇu un arhitektūras studentu Zigurdu Lazdiṇu ieguva dalītu otro un trešo prēmiju, izstrādājot projektu konkursa priekšlikumu komponistu jaunrades nama kompleksam Mellužos jūras tuvumā, starp Peldu un Dārza ielām. Celtne bija paredzèta zemes gabalā, kurā līdzena un klaja vieta atrodas blakus ar priežu mežu apaugušām kāpām [59]. Autori piedāvāja ap plašo, dekoratīvo pagalmu izkārtot četras sabloḳētu jaunrades kotedžu grupas. 
1978. gadā projektēšanas institūta «Pilsētprojekts» trešajā darbnīcā arhitekte Anda Ārgale D. Dannebergas vadībā izprojektēja Teātra biedrības ēku Vecrīgā, tagadējā Līvu laukumā, iepretim Krievu drāmas teātrim. Ēkā bija paredzēta publiskā dal̦a ar zāli, teātra kafejnīca 75 vietām, kā arī administratīvās telpas. Visai oriǵināls bija zāles risinājums - viena tās dalı tika projektēta ar pakāpjveidā izkārtotām skatītāju vietām, bet otra - kā eksperimentāliem uzvedumiem piemērota telpa. Ēkā tika ieprojektēts arī Vecrīgai raksturīgais iekšpagalms, ko varētu izmantot brīvdabas izrādēm [60].

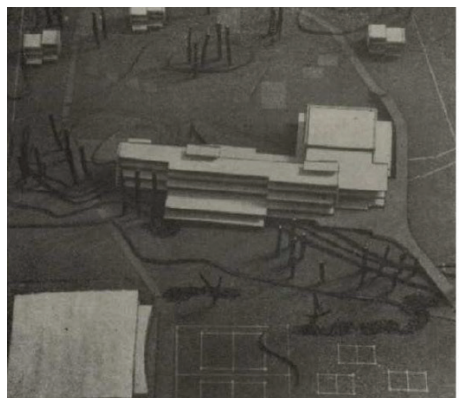

33. attēls. Komponistu jaunrades nama kompleksa projekts Mellužos (1967) [61].

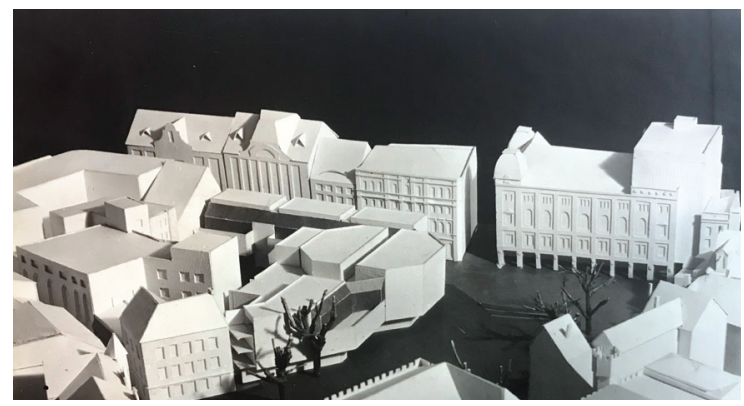

34. attēls. Teātra biedrības ēkas makets Vecrīgā (1978) [62].

1983. gadā pēc arhitektes D. Dannebergas projekta tika iesākts būvēt Latvijas Republikāniskās arodbiedrību padomes darbinieku kvalifikācijas celšanas kursu kompleksu Rīgā, Purvciemā, Rozes ielā, blakus Mēbel̦u namam. Kompleksā bija paredzētas mācību telpas 250 klausītājiem, aktu zāle, viesnīca, ēdnīca un neliela kafejnīca. Kompleksu bija paredzēts būvēt tā, lai tas kopā ar Mēbel̦u namu un pārējām ēkām veidotu noslēgtu laukumu autostāvvietām. Tā bija četrstāvu ēka dzelzsbetona konstrukcijās. Ëku nepabeidza celt [63].

20. gadsimta astonndesmitajos gados D. Danneberga projektēja vēl vairākas ēkas, kas vai nu netika realizētas vai to būvniecība netika pabeigta. Tādas, piemēram, bija mācību komplekss ar kopmītnēm «Intūrists» Dubultos un LVU Pedagogijas fakultātes jaunbūve Jūrmalas gatvē $74 / 76$.

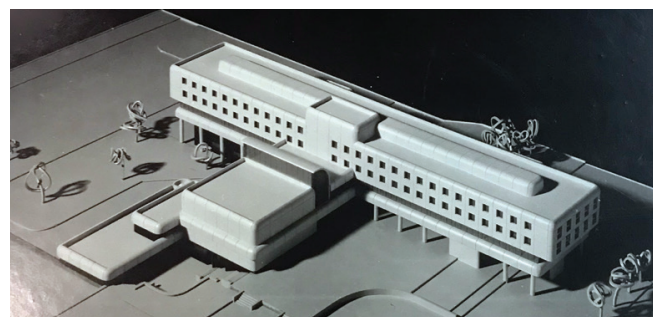

35. attēls. Arodbiedrības kursu kompleksa makets Rīgā, Augusta Deglava ielā 41a (1983) [64]. 


\section{Nobeigums}

D. Danneberga ir viena no Latvijā ievērojamākajām sabiedrisko un dzīvojamo ēku arhitektēm. Viṇas darbi ir kvalitatīvs pienesums Latvijas kultūrvidē. Tomēr šodien, neesot vienotam viedoklim par padomju laika 20. gadsimta celtṇu nozìmi un arhitektonisko kvalitāti, ir augsts risks zaudēt unikālas vērtības, jo tā laika celtnes nereti tiek brutāli pārveidotas vai pat nojauktas.

Gandrīz visi D. Dannebergas darbi ir mākslinieciski izteiksmīgas celtnes ar augstu kultūrvēsturisko vērtību. Tās ir raksturīgas sava laika būvmākslas augstāko sasniegumu liecības, kas kalpos vēl ne vienai vien sabiedrības paaudzei.

\section{INTEREŠU KONFLIKTS}

Zinātniskā raksta autori atzīst interešu konfliktu, kas saistīts ar autoru un redkolēgijas kopēju profesionālo darbību. Par šī raksta iekḷaušanu krājumā lēmumu pieṇēma tie redkolēǵijas locekḷi, kas nav raksta autori.

\section{AVOTU UN LITERATŪRAS SARAKSTS}

[1] Personāla dokumentu valsts arhīvs (turpmāk - PDVA) 959. f., 1. apr., 555. l., 231. lp.

[2] Foto no D. Dannebergas personīgā arhīva. No kreisās - Dainas māte Leontīne, māsa Guna un Daina dzīvoklī Rīgā (ap 1934).

[3] Foto no D. Dannebergas personīgā arhīva. Šūšanas uzṇēmuma «K. Kimelis» logo (1940).

[4] Foto no D. Dannebergas personīgā arhīva. Dannebergi nedēḷ pēc kāzām Mellužos (1949).

[5] Foto no D. Dannebergas personīgā arhīva. I. Veigners un D. Danneberga kāzu dienā (1960).

[6] Foto no D. Dannebergas personīgā arhīva. Daina Danneberga ar meitām Helgu un Noru (ap 1980).

[7] PDVA 959. f., 1. apr., 555. 1., 233. lp.

[8] Latvijas Universitātes (turpmāk - LU) arhīvs 49135. f., 6. lp.

[9] LU arhīvs 49135 f., 17. lp.

[10] LU arhīvs 49135 f., 29. lp.

[11] Eniña, A., Krastinšs, J. Creative Work of the Architect Daina Danneberga in the Context of Architectural Heritage of the Soviet Period (Arhitektes Dainas Dannebergas daiḷrade padomju laika arhitektūras mantojuma kontekstā). Scientific Journal of Riga Technical University. Architecture and Urban Planning. Vol. 4. 2010, p. 128. 
[12] PDVA 959. f., 1. apr., 555. l., 229. lp.

[13] Treija, S., Holcmane, V. Daina Danneberga. Latvijas Architektūra, 2014/2015 Decembris/Janvāris, Nr. 116, 104.-106. lpp.

[14] Jorēns, E. Pie Rīgas ziemel̦austrumu robežas. Rīgas Balss, 1963. gada 20. februāris, Nr. 43, 5. lpp.

[15] Tīlmanis, O. Arhitektūra, māksla un celtniecība. Māksla, 1960. gada 1. aprīlis, Nr. 2, 18. lpp.

[16] Jorēns, Ē. Par četriem arhitektiem un tukšo klajumu Juglā. Rīgas Balss, 1959. gada 26. augusts, Nr. 201, 3. lpp.

[17] Apsītis, V. Kopīgiem Spēkiem. Literatūra un Māksla, 1958. gada 29. novembris, Nr. 48, 1. lpp.

[18] Latvijas Arhitektūras muzejs (turpmāk - LAM) D21-5.

[19] Apkaimju vēsture: kā tika apbūvēta Rīga? [tiešsaiste]. https:// www.riga.lv/lv/news/apkaimju-vesture-ka-tika-apbuveta-riga?9625 [skatīts: 17.01.2018].

[20] Krauklis, O. Rīga Cel̦inogradai. Māksla, 1964. gada 1. aprīlis, Nr. 2, 18. lpp.

[21] Rīdzinieki uzcēluši kultūras pili jauno zemju apguvējiem. Dzimtenes Balss, 1964. gada 13. septembris, Nr. 74, 1. lpp.

[22] Krauklis, O. Rīga Cel̦inogradai. Māksla, 1964. gada 1. aprīlis, Nr. 2, 16. lpp.

[23] Дворец Целинников в Астане [online]. http://silkadv.com/ru/node/719 [cited: 15.01.2019].

[24] Конгресс-холл в Астане [online]. https://tonkosti.ru/\%D0\%9A\%D0\%BE $\% D 0 \% B D \% D 0 \% B 3 \% D 1 \% 80 \% D 0 \% B 5 \% D 1 \% 81 \% D 1 \% 81-\% D 1 \% 85 \% D 0 \% B E$ $\% D 0 \% B B \% D 0 \% B B \_\% D 0 \% B 2 \_\% D 0 \% 90 \% D 1 \% 81 \% D 1 \% 82 \% D 0 \% B 0 \% D 0 \% B$ $D \% D 0 \% B 5$ [cited: 20.01.2018].

[25] LAM 6320/D21.

[26] LAM 6320/D21.

[27] Krastinšs, J. Doma laukums. Mācību stunda Rīgas arhitektūrā. Diena, 1993. gada 31. jūlijs, Nr. 156, 12.-13. lpp.

[28] Gegere, A. 150 arhitektūras pieminekḷi. Rīgas Balss, 1975. gada 28. aprīlis, Nr. 99, 6. lpp.

[29] LAM D21-23.

[30] Foto I. Gudro. Latvijas Zvejnieku kolhozu savienības nams Jaunielā 13, Vecrīgā (2019).

[31] Bērziṇa, V. Eksperimentāla paneḷu apdare. Cīṇa, 1977. gada 14. jūlijs, Nr. 162, 2. lpp.

[32] Rīgas Tehniskās universitātes (turpmāk - RTU) Inženierzinātṇu vēstures pētniecības centra (turpmāk - IVPC) Vēstures muzejs (turpmāk - VM).

[33] LAM D21-8.

[34] Foto I. Gudro. Skats uz RPI Ķīpsalas studentu kopmītnēm (2008).

[35] Foto I. Gudro. Glazētās keramikas plāksnītes uz RPI Ķīpsalas studentu kopmītṇu fasādēm (2008).

[36] RTU IVPC VM.

[37] Ernštreite, V. Priežu sila ielokā. Zvaigzne, 1978. gada 15. maijs, Nr. 10, 4.-5. lpp. 
[38] Jaunas skolas. Austrālijas Latvietis, 1977. gada 5. augusts, Nr. 1389, 7. lpp. in the Context of Architectural Heritage of the Soviet Period (Arhitektes Dainas Dannebergas dailırade padomju laika arhitektūras mantojuma kontekstā). Scientific Journal of Riga Technical University. Architecture and Urban Planning. Vol. 4, 2010, p. 129.

[42] Enin,a, A., Krastiņš, J. Creative Work of the Architect Daina Danneberga in the Context of Architectural Heritage of the Soviet Period (Arhitektes Dainas Dannebergas daiḷrade padomju laika arhitektūras mantojuma kontekstā). Scientific Journal of Riga Technical University. Architecture and Urban Planning. Vol. 4, 2010, p. 41.

[43] Dripe, J. Ko turpmāk darīsim, kā tālāk iesim? Māksla, 1987. gada 1. marts, Nr. 5, 11.-13. lpp.

[44] LAM 6316-D21.

[45] Eniña, A., Krastinnš, J. Creative Work of the Architect Daina Danneberga in the Context of Architectural Heritage of the Soviet Period (Arhitektes Dainas Dannebergas dailırade padomju laika arhitektūras mantojuma kontekstā). Scientific Journal of Riga Technical University. Architecture and Urban Planning. Vol. 4, 2010, p. 130.

[46] LAM 6314/D21.

[47] Foto no Google Maps.

[48] LAM 6323-D21.

[49] D. Dannebergas skice - dzīvojamās ēka ar garāžu Kanāla ielā 5, Jūrmalā (2015).

[50] Foto no D. Dannebergas personīgā arhīva. Dzīvojamā ēka ar garāžu Kanāla ielā 5, Jūrmalā (2015).

[51] Rindu un bloḳēta dzīvojamo ēku projektu konkursa rezultāti. Literatūra un Māksla, 1958. gada 5. jūlijs, Nr. 27, 1. lpp.

[52] Prēmēti tikai dārza mājiṇu projekti. Literatūra un Māksla, 1959. gada 29. augusts, Nr. 35, 4. lpp.

[53] Holcmanis, A. Kāda būs Dailes teātra jauna ēka. Literatūra un Māksla, 1959. gada 12. decembris, Nr. 50, 3. lpp.

[54] Tīlmanis, O. Arhitektūra māksla un celtniecība. Māksla, 1960. gada 1. aprīlis, Nr. 2, 19. lpp.

[55] LAM Daina Danneberga D21-2.

[56] LAM D21-6.

[57] Danneberga, D. Rīgas panorāmas kinoteātrī būs 2300 vietas. Rīgas Balss, 1960. gada 5. aprīlis, Nr. 81, 5. lpp.

[58] Skalbergs, J. Komponistu jaunrades nama projektu konkurss. Literatūra un māksla, 1967. gada 6. maijs, Nr. 18, 8. lpp.

[59] Перевощиков, Ю. Дворец спорта [online]. http://riga.zurbu.net/tag:\%D0 \%9D\%D0\%B5\%D1\%80\%D0\%B5\%D0\%B0\%D0\%BB\%D0\%B8\%D0\%B7\%D0 $\% B E \% D 0 \% B 2 \% D 0 \% B 0 \% D 0 \% B D \% D 0 \% B D \% D 0 \% B E \% D 0 \% B 5 /$ feed [cited: 05.02.2019]. 
[60] Holcmanis, A. Jaunrades laboratorijas. Māksla, 1967. gada 1. aprīlis, Nr. 2, 18. lpp.

[61] Bērziṇa, V. Pilsētas rītdienai. Cīṇa, 1978. gada 15. jūlijs, Nr. 162, 3. lpp.

[62] Foto no D. Dannebergas personīgā arhīva. Teātra biedrības ēkas makets Vecrīgā.

[63] Danneberga, D. Jauns vaibsts Purvciema sejā. Rīgas Balss, 1984. gada 15. novembris, Nr. 259, 3. lpp.

[64] LAM 6319-D21.

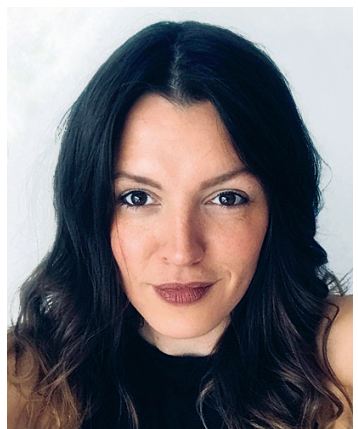

ILZE GUDRO, Dr. sc. ing., is currently Head of the Research Centre for Engineering History of Riga Technical University and a lecturer with the Institute of Design Technologies of RTU. Her main academic interests include the history of Riga Technical University, engineering sciences, interior, furniture and product design, materials science. She is a member of the team organizing the exhibitions of works of bachelor and master students of the Institute of Design Technologies of RTU (e. g. Fashion show «Kìpsalas Pavasaris», design product exhibitions «Kīpsalas Dizaina Kods», «Design Isle», etc.).

Address: 1 Kronvalda bulvāris, Room 203, Riga, LV-1010, Latvia

Phone: +371 28897223

E-mail: ilze.gudro@rtu.lv

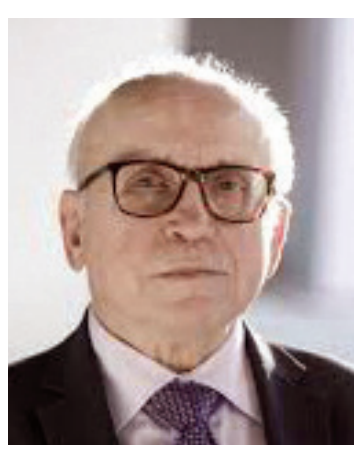

JĀNIS KRASTIN̦Š, Dr. habil. arch. (1991), is full member of the Latvian Academy of Sciences (1994, holder of the Great Medal 1998), Professor of Riga Technical University and a member of the Latvian Association of Architects (1970). He has designed numerous public and residential buildings and carried out investigations of historic structures. He is the author of more than 690 scientific works published in Austria, Belgium, Czech Republic, Denmark, Iceland, Italy, Estonia, Finland, France, Germany, Latvia, Lithuania, the Netherlands, Norway, Poland, Russia, Spain, Sweden, Turkey, the United Kingdom and the United States of America, including 28 books on various aspects of history and theory of architecture.

Address: 6 Kīpsalas iela, Room 412, Riga, LV-1048, Latvia

E-mail: janis_krastins_1@rtu.lv 


\section{Contribution of Architect Daina Danneberga to the Architecture in the Second Half of the 20th Century}

The article reflects the contribution of the renowned Latvian architect Daina Danneberga to Latvian architecture, as well as the significant events and growth of her life. While living and working in Soviet times, the architect has designed both residential and public buildings, which are still in use and whose cultural and historical significance has surely increased over time. The most recognizable object designed by the architect is the Student Campus of Riga Polytechnic Institute (RPI), now Riga Technical University (RTU), on the Kïpsala Island. It was designed by D. Danneberga from 1969 to 1986. The architect has also developed projects for several other educational institutions as well as public and residential buildings, both in Latvia and abroad.

Keywords: Daina Danneberga, RPI / RTU Kīpsala Campus, architecture of the second half of the 20th century.

Илзе Гудро, Янис Крастиньш

\section{Вклад архитектора Дайны Даннеберги в архитектуру второй половины XX века}

Статья отражает вклад выдающегося латвийского архитектора Дайны Даннеберги в латвийскую архитектуру, а также значимые события и факты ее жизни. Живя и работая в советское время, архитектор проектировала как жилые, так и общественные здания, которые все еще используются, и уровень их культурно-исторического значения, несомненно, со временем возрос. Наиболее узнаваемым объектом, проектируемым архитектором, является студенческий городок Рижского политехнического института (РПИ), ныне Рижского технического университета (РТУ) на Кипсале, над которым Д. Даннеберга работала с 1969 года по 1986 год. Архитектор также разработала проекты для многих других учебных заведений, а также общественных и жилых зданий, как в Латвии, так и за рубежом.

Ключевые слова: Дайна Даннеберга, студенческий городок РПИ / РТУ на Кипсале, архитектура второй половины XX века.
Arhitektes

Dainas

Dannebergas

devums

arhitektūrā

20. gadsimta

otrajā pusē 